Educational Research for Social Change (ERSC)

Volume 8 No. 2, September 2019

pp. 14-28

ersc.nmmu.ac.za

ISSN: 2221-4070

\title{
"I Recognised That I Needed To Look Searchingly at My Own Teaching": Storywork as a Self-Study Method for Educational Research for Social Change
}

\author{
S'phiwe Madondo \\ School of Education \\ University of KwaZulu-Natal \\ siphiwemadondo@ymail.com \\ Ntokozo Mkhize \\ School of Education \\ University of KwaZulu-Natal \\ ladyntoko@gmail.com \\ Kathleen Pithouse-Morgan \\ School of Education \\ University of KwaZulu-Natal \\ pithousemorgan@ukzn.ac.za
}

\section{Abstract}

Storywork is an indigenous research practice of making meaning through stories. This article offers an account of storywork as a self-study method for educational research. It brings into dialogue the distinctive personal stories of two South African primary school teachers, S'phiwe Madondo and Ntokozo Mkhize, who engaged in self-study research with the support of their supervisor, Kathleen Pithouse-Morgan. S'phiwe's and Ntokozo's storywork centred on stories of remembered childhood and adolescent experiences. The article presents S'phiwe's personal story piece, "An Outdoor School," which is accompanied by S'phiwe's reflection on his learning from the piece. Next, is Ntokozo's piece, "Lifetime Treasures," and her reflection. Then, S'phiwe's and Ntokozo's voices converge in a dialogue piece to demonstrate their mutually respectful, reciprocal learning in relation to the process of composing, reflecting on, and sharing personal stories. Writing and reflecting searchingly on these stories highlighted the pedagogic significance of finding out about children's and adolescents' cultural encounters and viewpoints, and incorporating these into learning and teaching. Additionally, engaging in storywork opened up possibilities for taking a simultaneously appreciative and critical stance on stories of the past, with the educative intention of contributing to educational and social change.

Keywords: dialogue, child and youth culture, indigenous research, self-study research, storytelling 
Copyright: (C) 2019 Madondo, Mkhize, \& Pithouse-Morgan

This is an open access article distributed under the terms of the Creative Commons Attribution NonCommercial License, which permits unrestricted non-commercial use, distribution, and reproduction in any medium, provided the original author and source are credited.

Please reference as: Madondo, S., Mkhize, N. \& Pithouse-Morgan, K. (2019). "I Recognised

That I Needed To Look Searchingly at My Own Teaching": Storywork as a Self-Study Method for Educational Research for Social Change. Educational Research for Social Change, 8(2), 14-28.

http://dx.doi.org/10.17159/2221-4070/2019/v8i2a2

\section{Setting the Scene}

Storytelling is a fundamental part of being human and of learning about relating to others in a social and cultural environment (Archibald, 2008; Iseke, 2013; Nash, 2004). Stories told in families, homes, and communities frequently take the form of idiosyncratic personal stories, which are inspired by unique lived experiences but are often told with a more general educative purpose (Iseke, 2013). This article brings into dialogue the personal stories of two South African primary school teachers, S'phiwe Madondo and Ntokozo Mkhize. S'phiwe and Ntokozo composed the stories as a central part of their postgraduate research with the aim of advancing their pedagogic knowledge and practice and contributing more broadly to educational and social change. Their inquiries can be regarded as storywork, which Archibald described as "the educational and research work of making meaning through stories, whether they are traditional or lived experience stories" $(2008$, p. 373). Archibald highlighted how "the process of learning to make meaning through stories . . . is a core part of Indigenous knowledge" (2008, p. 382). She conceptualised storywork as an indigenous research practice underpinned by cultural principles of "respect, responsibility, reverence, reciprocity," which she explained as "traditional values and teachings demonstrated toward the story, toward and by the storyteller and the listener, and practiced in the storywork context" (2008, p. 373).

S'phiwe's research focused on improving his practice to enhance English written communication among isiZulu-speaking Grade 6 learners (Madondo, 2014). As a teacher in an English-medium primary school where the majority of learners and teachers speak isizulu as their home language, S'phiwe had noticed how learners seemed to be struggling to express themselves through English written communication. In his research, he reflected on his childhood experiences in relation to learning written communication, and also scrutinised his own teaching practices with the aim of better understanding and improving his teaching of English written communication. In S'phiwe's understanding, having a flair for written communication means being able to express oneself using written language with creativity and flamboyance. He hoped that, through cultivating a flair for written communication in his classroom, he could motivate young people to develop a love for written communication. One consequence of S'phiwe's research was that he became more conscious of the importance of considering, and building on, youth culture as a pedagogic resource for cultivating a flair for written communication.

Ntokozo was seeking to explore and reflect on what she could learn about cultural inclusivityparticularly in relation to children's culture-from her own personal history. She was also researching how she could integrate children's culture as a pedagogic resource in her Grade 4 classroom in a primary school rich in diversity in terms of cultural heritage, religion, race, and language (Mkhize, 2016). She was interested in exploring children's culture by getting to know about games they enjoy playing, and connecting with their daily experiences and what they find interesting and intriguing. Through her research, Ntokozo gained insight into the everyday childhood adventures and challenges 
that can stimulate learning in the classroom, and into how children can create their own learning resources through toys and games.

S'phiwe and Ntokozo coauthored this article with their research supervisor, Kathleen PithouseMorgan, who has a particular interest in stories and storytelling in educational research (PithouseMorgan, Deer-Standup, \& Ndaleni, 2019). Kathleen worked with S'phiwe and Ntokozo to support their storywork. Prior to becoming a teacher educator, Kathleen was a schoolteacher. More than a decade ago, as a postgraduate student conducting research in her own classroom, she explored youth culture as a pedagogic resource for facilitating English creative writing with Grade 7 learners (Pithouse, 2003, 2004). Kathleen learned about how young people's motivation for, and interest in, creative writing could be enhanced by composing and sharing stories that reflected their own concerns and interests.

\section{Storywork as a Self-Study Method}

S'phiwe and Ntokozo both chose self-study methodology to research their own teaching. In S'phiwe's and Ntokozo's understanding, the most important features of self-study are questioning one's own practice from observations and personal experience, working with others who can offer useful advice and feedback and, lastly, trying out new methods of teaching to improve learning (Samaras, 2011). Self-study methodology involves multiple and varied methods (LaBoskey, 2004). The particular methods that each self-study researcher chooses depends on what she or he is trying to understand and how a certain method could assist in achieving that understanding (Samaras, 2011). Although $S$ 'phiwe and Ntokozo each used a range of self-study methods to generate data inside and outside their classrooms, the focus of this article is on their use of storywork as a self-study method for educational research for social change.

S'phiwe's and Ntokozo's storywork involved composing, sharing, and making meaning through personal stories of remembered childhood and adolescent experiences related to their research topics. In this way, their self-studies took a "holistic approach that acknowledges the intersection of the personal and the professional" (Pithouse, Mitchell, \& Weber, 2009, p. 58). As Samaras, Hicks, and Berger explained, "personal history-the formative, contextualized experiences of our lives that influence how we think about and practice our teaching-provides a powerful mechanism for teachers wanting to discern how their lived lives impact their ability to teach or learn" (2004, p. 905). In personal story writing, self-study researchers write about matters that are individually significant to them, and explore the relevance thereof for their professional practice and for educational and social change more broadly (Pithouse et al., 2009). As Pithouse et al. (2009, p. 51) observed, "the self-reflexive process of writing these [stories] can serve as a catalyst for action." This is because, as Iseke explained, "storytelling as witnessing and remembering allows engagement with ideas of the past and supports transforming ourselves today" (2013, p. 572).

Kathleen supported S'phiwe's and Ntokozo's storywork through frequent discussions and feedback. In narrating their personal history stories, $S^{\prime}$ phiwe and Ntokozo encountered memories of lived experiences that involved family members and friends. Kathleen encouraged S'phiwe and Ntokozo to only share stories that they would be comfortable with divulging publically and to respect the privacy and dignity of others implicated in these stories (Nash, 2004). Ellis (2007) cautioned that, when writing about family members and friends, we need to be aware of issues of relational ethics. She explained: "Relational ethics requires researchers to act from our hearts and minds, acknowledge our interpersonal bonds to others, and take responsibility for actions and their consequences" $(2007, \mathrm{p}$. 3). S'phiwe and Ntokozo discussed their storywork with family members and friends to explain the rationale for it and to ask for their blessing. S'phiwe and Ntokozo also gave reassurances that confidentiality would be respected and that no real names would be mentioned in the study. 
One of the most important characteristics of self-study research is learning through interaction with others (LaBoskey, 2004). While conducting their studies, S'phiwe and Ntokozo each worked closely with other postgraduate students in "critical friends teams" (Samaras \& Roberts, 2011, p. 43) to share ideas, pose questions, and offer advice. Because $S^{\prime}$ phiwe had already completed his study by the time Ntokozo's began, S'phiwe and Ntokozo were not in the same critical friends team. However, due to their shared research interests, S'phiwe, Ntokozo, and Kathleen chose to collaborate in bringing together S'phiwe's and Ntokozo's individual self-studies to consider how and what they learned through storywork.

The next section of the article offers S'phiwe's first-person personal story piece, "An Outdoor School" (adapted from Madondo, 2014). This is followed by S'phiwe's reflection on his learning from the piece. To follow, is Ntokozo's personal story piece, "Lifetime Treasures" (adapted from Mkhize, 2016), and her reflection. Then, S'phiwe's and Ntokozo's voices come together in a dialogue piece to show their reciprocal learning in relation to the process of composing, reflecting on, and sharing their personal stories. The chapter closes with a consideration of the transformative possibilities of storywork as an educational research practice.

\section{S'phiwe's Personal Story Piece: "An Outdoor School”}

Growing up as an African boy in the 1980s in a rural area of South Africa where Zulu culture was dominant was full of challenges and expectations from peers and from elders of the community. The community was closely knit and we knew everyone in our neighbourhood. Elders of that time believed it takes a village to raise a child. In isiZulu, this is expressed as Umuntu ophilileyo wakhiwa yisizwe esiphilileyo. We were taught that every elderly person you met was your parent and had as much right as your biological parent to discipline you if you were behaving in an unacceptable way. The observation of protocols for the community leadership, for example the chief and iNduna [village leaders appointed by the chief], were of utmost importance-especially when it came to social gatherings, which were expected to be reported to the authorities well in advance. Particular values were emphasised and passed on from generation to generation, teaching a philosophy of respect and humanity (known as ubuntu). We were brought up in a manner that also inculcated traditional values of the Zulu culture with respect to gender identity; there were cultural activities that were genderorientated because boys were being prepared to grow into manhood, and girls prepared to become women.

One crucial cultural activity I had to engage in as a growing young boy was cattle herding (ukwalusa). It was considered important by most elders, especially male parents, to have their sons take part in this "outdoor school" where boys taught each other many skills that prepared them to be strong men who understood and valued their culture. Even if your parents did not own any cattle, you were expected to take part and accompany neighbourhood boys. If you did not take part, you were considered a mother's boy (umnqolo) who would not grow to be a real man.

I consider cattle herding an informal school because, during school holidays and on weekends, I had to leave home to herd in the morning, only returning late in the afternoon. On school days, we herded in the afternoons so I never missed formal schooling because of cattle herding. When we got to the veld, we met boys from other villages bringing their cattle to graze, after which we took the herd to a nearby river to drink water. While the cattle grazed, we had time to learn "boys' stuff." 
The first lesson was to learn to communicate with the herd. I was taught how to shape my mouth to whistle to communicate with the cattle because they sometimes disappeared while we were busy. I would also whistle as a sign of warning if the cows were going towards the mealie fields. Cattle were named by their owners, and each one's name had a history behind it. Some were named after food for example, sosishi [sausage] or after kitchen utensils, thispuni, mfoloko [teaspoon, fork] or after the place where they were bought or where the owner worked, for example, uMkhomazi, nTransvali (uMkomaas, Transvaal).

To encourage the bulls to fight, we sang praise songs in a skilled way to evoke the impulse for a fight. As Molefe explained, "praises are chanted to encourage the bulls to fight gallantly" (1992, p. 21). The cattle knew whether songs were sung by their herders not. If songs were sung by strangers, the cattle would just ignore them. The praise songs were sung again and again, repeating the name of the bull several times because, most of the time, the praises emerged from its name. I remember that at home we had one bull named after a kitchen utensil basket (Bhaskidi). That was a bull we were proud of because he was good at fighting. This bull had so much strength and power to fight! He showed resilience in many encounters. Bhaskidi's praises were: Bhaskidi welala! Bhaskidi welala! Uyangene makethe! Bhaski, Bhaskidi, Bhaskidi!

I recall how, even if a bull was grazing, when we sang his praise song he would start to dig the ground with his horns and make a growling sound, signalling his readiness for a fight. If two herders sang their praise songs at the same time, it meant their bulls would be involved in the fight because they would recognise their names in the praises. The two bulls would fight until one ran away, meaning he was defeated by the other. Whenever my bull was involved in a fight, I felt anxious and I crossed thumbs for good luck because I hoped for a win on every match.

Because we spent many of our days in the veld, we learned to entertain ourselves by designing musical instruments such as guitars from 5 -litre oil tins with a few fishing strings added. Music was another creative form of communication that I learned. When playing the guitar, we composed lyrics that came from within our selves to make songs. These songs varied from happy to sad songs, depending on an individual's mood at the time of composition. We used music to express our inner thoughts and to communicate with the environment surrounding us. Sometimes we made up songs to praise our cattle or to relate a specific event that had occurred while we were herding. The music was mostly traditional, and the others would chant, dance, and whistle to the beat of the guitar. Soul songs were also composed, in which the singer might express his feelings about something he appreciated, or sing about an event he had experienced. Cattle herding is where many well-known Zulu traditional singers (for example, Phuzekhemisi, Mqabulasheshe, and Mfaz'omnyama) began to notice and nurture their talent. However, the problem with our musical performances was that we lacked an audience because there was never opportunity for the whole village to come and enjoy the music.

To alleviate hunger while herding, we learned to provide food for the day. We made special tools to hunt for animals such as birds and rabbits in the surrounding area. We collected wood to make a fire to cook the meat, or we set alight an anthill that worked as an oven-we also used these as heaters in cold weather. We swam to cool down during hot days, which was very unsafe because we were not sure of the water depth in the dams and rivers, and there could be dangerous animals such as crocodiles. However, we enjoyed swimming. Anyone with a little swimming experience was a coach. I remember I nearly drowned when someone pushed me into the centre of a deep dam before I had learned to swim - l could not keep my head above water. Fortunately, the other boys quickly recognised that I was struggling and some came to assist me. I was so frightened, and never mentioned that dreadful event at home and made a promise to myself that I would never try swimming again without adult supervision. It was a scary experience. 


\section{S'phiwe's Reflection on His Personal Story Piece}

In retracing my memories to compose this personal story, I became conscious of the importance of considering youth culture when teaching written communication. Written communication is learned through language, and language is culturally constructed and reconstructed (Kajee, 2011). Moletsane (2011) highlighted how an individual's cultural identity is affected by different factors at different moments and in different places. Moreover, Ndaleni (2013) pointed out that at certain points in time cultural practices can became outdated. Thus, I had to keep in mind that the cultural activities we practised in my youth might be totally different and irrelevant to those practised by today's youth. For example, Social Media in Learning and Education (SMILE, 2013) clarified how the connotations of the word "friend" illustrate how technology may be shifting language use for young people who meet and connect virtually with friends through social media.

The significance of youth culture for learning emerged from my storywork. For example, when we were herding cattle as children, we taught one another many lessons about being an African boy. Some of these lessons were very useful in life in general. It was believed by my community that if you were a boy you should be in involved in this youth cultural practice of cattle herding. Moletsane (2011) explained that culture "encompasses in addition to art and literature, lifestyles, ways of living together, value systems, traditions and beliefs . . . culture is learned, shared, and integral to an individual or group's sense identity" (p. 195). In addition, Mkhize (2004) explained culture as information that is cascaded from one generation to another by members of a society or community, through which they to gain a sense of identity. Likewise, knowledge that we gained from the youth cattle herding culture was passed from generation to generation. However, through looking back, I can see that the cultural knowledge and lessons learned from environmental interactions while herding were not used by my teachers to contextualise their lessons. Through my storywork, I now realise the negative impact on me for my former teachers not to use my cultural knowledge as a resource in my learning of written communication.

Ndaleni (2013) demonstrated in his self-study research how the cultural practice of storytelling played a vital role in informing his style of teaching by assisting him in selecting topics that were of genuine interest to learners. Similarly, Meyiwa, Letsekha, and Wiebesiek (2013) argued that it is important to value indigenous knowledge and experience in education. This means that teachers can learn a great deal by using local people's indigenous knowledge to inform educational activities. Therefore, in my teaching of written communication, I decided to encourage my learners to use and build on their cultural practices and knowledge when communicating through writing. For example, in some creative writing activities, I allow them to write using the texting style they use when writing messages on their cell phones. In this way, we are using their youth culture as an educational resource.

Learners come to school with a home background and teachings that are grounded in language and cultural practices (John-Steiner \& Mahn, 1996). This means that learners start schooling not as empty vessels but with informal knowledge learned or taught as part of everyday life. This kind of knowledge is evident in my personal story piece, "An Outdoor School." Therefore, the lessons learned from cultural practices at home, and those from school in the teaching of written communication, need to inform and complement each other. This means that language and culture, together, can form a foundation for teachers to build written communication.

Kajee (2011) asserted that learners can expand how they understand literacy by participating in culturally relevant literacy practices. However, this was not the case in my experience of schooling because we were not given opportunities to write about our own lives. I now see that our teachers should have given us a chance to write about issues that were culturally and socially meaningful to us to encourage us to take part in writing activities more willingly. For example, they might have asked us 
to write about our experiences of cattle herding activities rather than write stories on prescribed topics that had little relevance for us. Possibly, our written communication would have improved faster because it would have been more relevant to our lives and context. Meyiwa et al. (2013) affirmed that using local people's knowledge and experiences can enhance the school curriculum and create a link between the school and the community. Correspondingly, Conolly et al. (2009) maintained that when learners can identify their own personal and cultural experience in classroom activities, they learn more successfully and competently. By contrast, the knowledge I gained from herding as a cultural practice was never used to develop my written communication at school. Teachers never gave us a chance to express our thoughts on our cultural practices.

I have learned that, when teaching written communication, teachers have a responsibility to seriously consider, and build on, learners' existing knowledge learned through cultural practices. Learning to communicate through writing makes more sense when it is learned in a cultural and social context (Kajee, 2011). By means of storywork, I have discovered that I should allow my learners to choose topics that are relevant to their cultural experiences and immediate contexts. Youth culture plays a significant role in young people's lives, and should not be left out of what we teach. Moreover, I have become aware that the cultural practices that were prevalent during a teacher's formative years may become outdated and irrelevant and so it is vital for teachers to be up to date with the latest practices so that lessons relate to what learners are familiar with and interested in.

Overall, reflecting on my personal story helped me to want to not repeat what my teachers had done to me but, instead, to do justice in all my classroom lessons for written communication. Storywork as a self-study method changed my thinking about the long-term consequences of personal experiences. Storywork assisted me to realise that I can build on the unpleasant and unimaginative experiences I encountered during my formal schooling to develop new teaching strategies. The process of writing my story helped me understand that teaching practices can be enhanced when teachers have a chance to revisit their past experiences, and to think about how they can draw important lessons from them.

\section{Ntokozo's Personal Story Piece: “Lifetime Treasures”}

I do not have a vivid memory of my first day in Grade 1 in 1996. I just recall waking up in the early hours of the morning. The sound of the rooster and the hens cackling always prepared me for my mornings. Some days were assertively cold. I could not even feel my hands or nose. At the time, we lived in a township ${ }^{1}$ called Umlazi. However, my parents had enrolled me in a school in the formerly Indian area ${ }^{2}$ of Merebank because they thought it would offer a better education than the nearby township schools. ${ }^{3}$ If memory serves me well, Merebank was almost an hour away from our home and so I used the malume system to get to school. Malume means "uncle" in isizulu, and it is a transport system that collects learners from a neighbourhood who go to the same schools or schools situated around the same area. Parents pay the malume on a monthly basis, and this transport system is still called malume by our learners and our school community. I must say it was always comforting to have a big bowl of warm porridge just before malume arrived.

\footnotetext{
${ }^{1}$ In South Africa, a township refers to a suburb or city of mainly black occupation, formerly and officially designated for black occupation during the apartheid era (Township, n.d.).

2 In 1950, the apartheid government passed the Group Areas Act. This Act enforced the segregation of races by zoning them to specific, separate residential areas. This legislation was repealed in 1991 (Clarke \& Worger, 2016).

${ }^{3}$ During apartheid (1948-1994), South African schools were segregated and inequitably funded according to race, with black schools receiving the least funding and resources. Much of this inequality remains in postapartheid South Africa (Clarke \& Worger, 2016).
} 
When I started Grade 1, it was probably the first time I was introduced to people of other races, and who spoke English. My home language is isizulu and I remember spending most of the time frantically trying to speak and understand English. We did our daily news every Monday and I struggled to express myself because I could not speak English fluently. I still remember my white school uniform and the navy belt that was never a perfect fit. My knees and elbows were always dry, especially during winter. My parents had probably invested a lot of money buying pencils, shoes, and belts that were frequently getting lost. As usual, I would fail dismally to trace these or explain how I had lost my belongings.

My eyes were drawn to pictures and colours. I remember seeing different colours, numbers, books, and alphabets around the classroom. I recall sitting on the carpet during reading or storytelling times. Most of our readers rhymed. Through reading, I was introduced to fairy tales, myths, goblins and I was always anxious to hear the ending of the story. Of course, I loved happy endings. I remember that some of the stories correlated with my daily experience, such as waking up in the morning and getting ready for school. Story time stimulated our imaginations as we tried to sequence the story line and speculate on how the story would end. I remember connecting some of these stories to cartoons and programmes we watched on the television at home. Reflecting on these moments made me realise that we were taught moral values at a very young age. For example, in The Three Little Pigs we learned that we must always work with dedication and be prepared for anything, as well as to think cautiously and critically. I also became interested in learning English through these stories. My father would speak English with me and help me with reading.

I was also introduced to Santa Claus and Hindu gods at this school. Looking back, I can see that this created confusion because I could not find my own cultural identity. My family went to church on a regular basis, but Santa Claus was taboo in my house. My parents were never exposed to Christmas and the idea of Christmas. They just believed it was Jesus' birthday. It had never crossed my mind that different beliefs and religions existed outside my own cultural heritage and my family's religion. This was a peculiar discovery.

In 1997, my parents informed us that we would be moving to Newlands West, a formerly Indian area. They described our prospective home as spacious and with a lovely yard. I was excited about having my own room. I imagined how I would decorate my room, and visualised playing in an open yard with flowers, a guava tree and, of course, a juicy mango tree. I imagined the smell of the lemon trees, the Indian curries, and the sounds of Eastern Mosaic music. My grandparents could not help but boast about us moving to an area where people of other races lived, predominantly Indian peoplealthough, I had never identified myself as belonging to any race until my family discussed it with us.

However, my thoughts attempted to conspire against me. While I was aroused by excitement, I was also subdued by apprehension. Mutely, I convinced myself that I could change their minds. How was it possible that we were moving from Umlazi to Newlands West? There was so much good that was happening in Umlazi. And I had just adapted to the school in Merebank. It finally felt like I was making progress academically and socially. Looking back, I can see that I did not apprehend that I was imprisoning myself with my emotions and lack of interest to try new avenues. Fearfully I gave in; I could not comprehend the depth of my agony at leaving my friends and some family members behind. My mother explained how beneficial it was for our family to move. My father painted my imagination and described everything he felt I could fall in love with at our new home. My parents explained that they were concerned about our safety and security in Umlazi. They were certain that this new home offered those two qualities, not to mention that it had good neighbouring schools. This meant more hours of sleep with only a short distance to travel to school. 
I was seven years old, almost eight, when we moved to Newlands West where I soon made new friends. I recall the games we played inside and outside, and the television shows we were drawn to. These were inspired by my neighbours who later became lifelong friends. We enjoyed watching Denis the Menace, Karate Kid, Power Rangers, Ninja Turtles, Aladdin with his magic carpet, and Pocahontas. I was also introduced to board games such as Scrabble, Monopoly, and playing cards. Before this, I never knew that staying indoors could hold an element of entertainment. On adventurous days, we did not mind getting our hands grimy by visiting the nearest dam in our neighbourhood. We would make glorious sounds accompanied by horror as we alarmed our parents because the boys had frogs, crabs, or insects to scare us. Even though we were petrified, we enjoyed the ecstasy of evading them and telling tales.

Our fun knew no weather conditions and had no boundaries. I remember how we spent rainy days dancing and singing in the rain and chanting to the rain gods. Our parents never understood why we were amused by playing in the rain, hounding caterpillars and grasshoppers, and running away from the wild monkeys that waltzed into the house. The monkeys were always up to no good, messing my mother's garden and eating from the dustbin as they wrestled for mangoes and guavas. If we were not chaotic, then the monkeys were causing havoc. Because of the monkeys, the yard was never clean and my mother rarely reaped her vegetables.

I recall religious celebrations in our neighbourhood, such as Diwali, the Hindu festival of lights that takes place in October and November. It is chiefly associated with Lakshmi, the goddess of prosperity. Hindu people give expression of happiness through setting off fireworks and inviting close friends and family to feast on delicious food. The Hindus also light lamps as a way to pay obeisance to the gods for the success of health, wealth, knowledge, and peace. The night of Diwali would be filled with bright colours. I didn't know what the festival stood for but I knew that my parents would not approve if we ate anything that had been prayed for by Hindus.

My friends and I enjoyed long conversations about our future endeavours. We would share tales and myths told by our great grandparents. We would look deep into the dark blue evening sky filled with stars, waiting for a shooting star so we could make a wish just like in the movies. We would imagine that a family lived in the moon and that they controlled the night and the galaxy. It was phenomenal. I can say it made me forget most of my troubles. Through back looking at my childhood experiences, I have come to realise that as children we had our own culture.

At home, I was never really exposed to gender discrimination because girls and boys were treated equally in my household. My parents made joint decisions on finances and academics, as well as socially. However, during visits to my grandparents in a rural area, a patriarchal society was revealed to me through traditional Zulu ceremonies and rituals where men would slaughter animals and burn incense for a gravestone or thanksgiving and seek ancestral guidance. At these ceremonies men had to be served first, women were not allowed into the kraal (where livestock is kept), and only boys were allowed to milk the cows. Such things looked and sounded so foreign to my eyes and ears! When I questioned certain things, I received negative comments and looks from other young women or was called to order by elders. Those comments indicated automatic respect for, and superiority of, men together with their importance in all levels and parts of life. Also, children's agency had no place in this traditional society; we were simply not considered, or regarded as people with thoughts and opinions.

\section{Ntokozo's Reflection on Her Personal Story Piece}

Looking at my story, I am reminded of the diverse beliefs I was exposed to, such as traditional Zulu cultural beliefs and Christianity. My family drew their strength from and practised both these sets of 
beliefs. This created a lot of confusion for me. Even now, I find that we have to do both Christian and traditional practices. Therefore, in my teaching I should aim to encourage my learners to celebrate their cultural diversity and not try to fit into one cultural heritage or another. I realise the importance of creating a learning environment that understands and respects differences. My storywork also reminded me of relocating from Umlazi to Newlands West and living in a community with people who practised a different religion. I recalled how we watched our neighbours chant, burn incense, and light candles. They also fed their gods and idols. This was all new and intriguing for me, and different from what I knew.

While writing the story, I realised there were differences in beliefs between what I practised at home and what I practised at school, especially when we moved to Newlands West. I found that I had had a hard time identifying with a particular religion. At home, we believed in Christianity and Zulu traditions. It was surprising to me to find out that my Indian neighbours also burned incense; when they burned incense it was about communicating with their gods and we burned incense when we called on ancestors. At the festival of Diwali, I recall seeing vibrant colours and lights, and I appreciated the sound of fireworks as well as the aroma of Indian food. At school, we celebrated Diwali-but we also celebrated Christmas. We would receive Christmas presents from our teachers and we would have Santa Claus. When I went home I would ask my parents about Santa Claus, but they did not know about him, which created a lot of confusion for me. I had a very hard time trying to adapt and trying to figure out where I belonged.

In narrating my personal story, I relived the exciting colours, scents, and tastes of the time I spent playing with my childhood friends. I was inspired by Mitchell and Reid-Walsh (2002) who reminded me that engaging with our childhood memories can remind us as teachers about the importance of childhood play and engagement with children's popular culture. As Nkopodi and Mosimege advised, "this enjoyment of the game can be used to enhance the learners' interest" in the classroom (2009, p. 389). Motivated by my storywork, I have realised that there is a culture of learning that exists outside the classroom. This assisted me in realising that I did not want to cultivate passive learners but, rather, learners who were active. I had to walk in their footsteps, reflect on my own childhood experiences, and question whether or not I was embracing and integrating the children's culture. As Johanson (2010) pointed out, research conducted in schoolyards and playgrounds has highlighted that children have their own culture. She also emphasised that children have their own particular values. Based on this understanding, I realised I could not turn a blind eye to what drives and motivates my learners. Mitchell and Reid-Walsh (2002) further stressed the importance of listening to children's voices and perceptions as displayed in their daily encounters and activities, their interests, and passions. I found it fascinating to think of children as active resources that play a pivotal role in learning and teaching.

In reflecting critically on my story, I also recalled how women were viewed in the more traditional community I experienced while growing up and visiting my grandparents' home in a rural area. In that community, we girls were expected to be submissive, to be nurturing, and to be subordinate. We were supposed to know that men were superior in their households. This reminded me of du Preez and Roux who cautioned, "there is a need to have dialogues on values in our different contexts as a way of assisting us to transcend our comfort zones" (2010, p. 24). I recognised that I needed to look searchingly at my own teaching to contemplate how I could find a way to help learners negotiate their way between traditional cultural values they are exposed to, and the human rights values that are enshrined in our South African constitution.

I have learned that self-study research allows us to reevaluate our teaching and the way we address certain issues. Storywork as a self-study method gave me an opportunity to learn from my past experiences, to reflect on and inquire into myself and my practice, in order to grow and improve my 
teaching and learning. I advise others interested in self-study research to be prepared to be criticisedand to criticise yourself, to search beyond your own perspective, and to know that there is always room for improvement.

\section{Dialoguing}

The dialogue piece presented in this section, facilitated by Kathleen, communicates S'phiwe's and Ntokozo's reciprocal, mutually respectful learning from sharing their personal story pieces with each other. The short exchange draws on the narrative element of dialogue (Coulter \& Smith, 2009), which is used in storytelling to show how characters act and develop in relation to each other. The dialogue is also informed by narrative thinking as a mode of thinking for qualitative research analysis (Freeman, 2017). As Freeman explained, "the strength of narrative thinking is in its ability to make visible the interpretive capacities of human agents in relation to their actions, interactions, beliefs, and practices" (2017, p. 43).

\section{Kathleen: S'phiwe and Ntokozo, has your learning been developed through sharing in each other's storywork? Please explain.}

S'phiwe: My ideas have been developed. From Ntokozo's storywork, I have learned that honouring a diversity of learners' cultural backgrounds in classrooms can teach learners to appreciate and to understand one another better, and they can draw valuable lessons from different cultural practices and interactions. Furthermore, her storywork confirms for me that children's culture can be a very useful resource for teaching because it encompasses learners' interests, values, and interactions that exist outside of the school context. Ntokozo's storywork further enlightened me about how important it is for us as teachers to understand how issues of gender and power impact our classrooms and communities. I have also become more conscious of how teachers' personal history storytelling could assist them to better understand how crucial their own cultural interactions were in shaping who they are, and the knowledge they gained, so that they can realise the need to allow children's culture to inform their teaching. Storywork also gives the writer or storyteller a chance to find new understanding and meaning in some of cultural practices that were instilled during childhood so that her or his viewpoint on certain outdated practices can change.

Ntokozo: From S'phiwe's storywork, I understand that my learners are walking resources and tools for education; I need to constantly tap into their perspectives and reality, which can allow me to be aware of their culture of learning and their interests. Children come alive when learning is connected with what they find intriguing. When we take the time to involve our learners in our teaching we are actually climbing into their imaginations and their adventures. This can keep the classroom alive and interactive and create a learning space that is full of hope and new exciting possibilities.

\section{Kathleen: How and why does this matter to you as educational researchers and as teachers?}

S'phiwe: Our personal history stories show the personal and social values of research on bringing learners' popular culture into teaching the prescribed curriculum. This matters to me as a teacher because I had not consciously incorporated learners' cultural knowledge in my teaching in the past. This might assist me to get learners' highest level of participation because it could stimulate their interests in the classroom given that they will be using knowledge that is original, and which gives them a sense of identity. This could matter to other teachers who seek not to repeat the same mistakes as those made by their former teachers who did not integrate cultural knowledge in their teaching. This could also matter to teachers because they can make use of learners' cultural experiences to make their teaching and learning more meaningful and interesting to learners. Learners might feel confident and proud because their learning will be relevant to what they know. It is important for teachers to 
treat each child as a unique individual and they should try to adapt to see things from learners' viewpoints by learning about their cultural practices and experiences.

Ntokozo: Through storywork, I have been able to identify parts of me I never knew existed. I have also discovered that learning takes place long before we are enrolled in an educational institution because we learn through our daily encounters, social interactions, sharing ideas, and solving mysteries. I understand that, in order to grow in my profession, I need to constantly revisit my childhood memories, and question and reflect on my teaching practices. I am pleased to say that this has allowed me to flourish in my teaching and learning. I have adopted a determined spirit to influence my learners in a positive manner through writing my own story. I find it important because storywork as a selfstudy research method reveals that we do not learn individually; we also cannot isolate our past from our present. I understand that, through reflecting on and revisiting my childhood memories, I can identify my shortcomings as a teacher and possibly engage in collaborative learning, critical thinking, and thought-provoking tasks that inspire my colleagues and critical friends to feed our learners academically, emotionally, and socially. I anticipate that this will allow us to be our own authors and to share our stories in ways that can aid and influence the way we, and others, learn and teach. As teachers, we often disregard our learners' ideas; looking at how we felt and what we experienced as children could possibly ignite hope and optimism in our classrooms. I want my learners to look forward to coming to my classroom; I want to give them and myself treasured moments in the classroom that develop them as resilient, passionate, and determined individuals.

\section{Closing}

The storywork and dialogue piece presented in this chapter illustrate how "storytelling as a research practice enables the researcher to engage with the stories and histories of families, communities, and cultures and to begin the transformative process of understanding oneself in relation" (Iseke, 2013, p. 573). Storywork enabled S'phiwe and Ntokozo to see themselves and their learners as embedded in a web of personal, cultural, and social relationships that cannot be left outside the classroom. Composing and reflecting on their own personal history stories facilitated a growing awareness of the pedagogic value of seeking out learners' cultural experiences and perspectives and integrating these, where appropriate, into learning and teaching. In addition, they both came to an awareness that storywork can open

a space or spaces for both critical debate and reflection about the past and its impact on the present and the future and for imagining what a different and desirable future (or futures) might look like and how we might get to it. (Moletsane, 2011, p. 206)

As Coulter and Smith emphasised,

because of the conventions of education research, researchers tend to write as if they were viewing events from a great distance . . . as if to convey to the reader a sense that no human being had a hand in the study. (2009, p. 584)

By contrast, the juxtaposition of S'phiwe's and Ntokozo's personal stories offer an encounter with the richness, texture, and complexity of human experiences that are unique and yet, interconnected. The dialogue piece conveys how although each teacher-researcher's storywork

is located in connection to the storytelling context . . this seeming specificity does not limit the value of the research to a single location or event because the transformative 
effect of the stories can continue with those who hear the stories and take up the challenges of transformation posed in the stories. (Isek, 2013, p. 573)

For Kathleen (whose childhood experiences were, in many ways, unlike S'phiwe's and Ntokozo's), their rich personal stories illustrate how storywork can bring someone else's experience into the reader's or listener's direct, felt experience in a way that generates empathy and insight-often with a transformative effect.

As a whole, this article offers an exemplar of self-study research that has implications for a wider audience. Through bringing S'phiwe's and Ntokozo's authentic personal stories and perspectives into dialogue, the article portrays the power of storywork as a self-study method for transformation on personal and professional levels - which leads to changes in educational practice. This, in turn, influences learners and others within multiple spheres of interaction. Thus, education and our social world are ultimately changed for the better.

\section{Acknowledgments}

We gratefully acknowledge grant funding from the National Research Foundation of South Africa (Incentive Funding for Rated Researchers). We further acknowledge that any opinion, findings, and conclusions or recommendations expressed in this material are those of the authors and therefore the funders do not accept any liability in regard thereto.

We would like to highlight the contributions of the two critical friends teams who supported S'phiwe and Ntokozo in their self-study research.

We are appreciative of the critically constructive feedback from the anonymous peer review process.

\section{References}

Archibald, J. (2008). An indigenous storywork methodology. In J. G. Knowles \& A. L. Cole (Eds.), Handbook of the arts in qualitative research (pp. 371-393). Thousand Oaks, USA: SAGE.

Clarke, N. L., \& Worger, W. H. (2016). South Africa: The rise and fall of apartheid (3rd ed.). Abingdon, UK: Routledge.

Conolly, J., Desmond, S., Dullay, S., Gumede, J., Mnguni, E., Ngaloshe, C., . . Yeni, C. (2009). The self as a laboratory of awareness: Exploring the oralate-literate interface of memory. In K. Pithouse, C. Mitchell, \& R. Moletsane (Eds.), Making connections: Self-study \& social action (pp. 97-112). New York, USA: Peter Lang.

Coulter, C. A., \& Smith, M. L. (2009). The construction zone: Literary elements in narrative research. Educational Researcher, 38(8), 577-590.

du Preez, P., \& Roux, C. (2010). Human rights values or cultural values? Pursuing values to maintain positive discipline in multicultural schools. South African Journal of Education, 30(1), 13-26. Retrieved from http://www.sajournalofeducation.co.za/index.php/saje/article/view/313/190

Ellis, C. (2007). Telling secrets, revealing lives: Relational ethics in research with intimate others. Qualitative Inquiry, 13(1), 3-29.

Freeman, M. (2017). Modes of thinking for qualitative data analysis. New York, USA: Routledge.

Iseke, J. (2013). Indigenous storytelling as research. International Review of Qualitative Research, 6(4), 559-577. 
Johanson, K. (2010). Culture for or by the child? “Children's culture" and cultural policy. Poetics, 38(4), 386-401.

John-Steiner, V., \& Mahn, H. (1996). Sociocultural approaches to learning and development: A Vygotskian framework. Educational Psychologist, 31(3/4), 191-206.

Kajee, L. (2011). Literacy journeys: Home and family literacy practices in immigrant households and their congruence with schooled literacy. South African Journal of Education, 31(3), 434-446. Retrieved from http://www.sajournalofeducation.co.za/index.php/saje/article/view/545/263

LaBoskey, V. K. (2004). The methodology of self-study and its theoretical underpinnings. In J. J. Loughran, M. L. Hamilton, V. K. LaBoskey, \& T. Russell (Eds.), International handbook of self-study of teaching and teacher education practices (Vol. 2, pp. 817-869). Dordrecht, Netherlands: Kluwer.

Madondo, S. (2014). Nurturing learners' flair for written communication: A teacher's self-study (Unpublished master's thesis). University of KwaZulu-Natal, South Africa. Retrieved from http://researchspace.ukzn.ac.za/handle/10413/12626

Meyiwa, T., Letsekha, T., \& Wiebesiek, L. (2013). Masihambisane: Lessons learnt using participatory indigenous knowledge research approaches in a school-based collaborative project of the Eastern Cape. South African Journal of Education, 33(4), 1-15. Retrieved from http://www.sajournalofeducation.co.za/index.php/saje

Mitchell, C., \& Reid-Walsh, J. (2002). Researching children's popular culture: The cultural spaces of childhood. New York, USA: Routledge.

Mkhize, N. (2004). Sociocultural approaches to psychology: Dialogism and African conceptions of self. In K. Ratele, N. Duncan, D. Hook, N. Mkhize, P. Kiguaw, \& A. Collins (Eds.), Self, community \& psychology (pp. 5-1-5-31). Cape Town, South Africa: UCT Press.

Mkhize, N. S. (2016). Integrating cultural inclusivity in a Grade 4 classroom: A teacher's self-study (Unpublished master's thesis). University of KwaZulu-Natal, South Africa. Retrieved from http://researchspace.ukzn.ac.za/handle/10413/14891

Molefe, L. (1992). An analysis of the praises of domestic animals (Unpublished master's thesis). University of Natal, South Africa.

Moletsane, R. (2011). Culture, nostalgia, and sexuality education in the age of AIDS in South Africa. In C. Mitchell, T. Strong-Wilson, K. Pithouse, \& S. Allnutt (Eds.), Memory and pedagogy (pp. 193-208). New York, USA: Routledge.

Nash, R. J. (2004). Liberating scholarly writing: The power of personal narrative. New York, USA: Teachers College Press.

Ndaleni, T. (2013). Teaching English oral communication to isizulu-speaking learners in a secondary school: A self-study (Unpublished master's thesis). University of KwaZulu-Natal, South Africa. Retrieved from http://researchspace.ukzn.ac.za/handle/10413/11506

Nkopodi, N., \& Mosimege, M. (2009). Incorporating the indigenous game of morabaraba in the learning of mathematics. South African Journal of Education, 29(3), 377-392. Retrieved from http://www.sajournalofeducation.co.za/index.php/saje/article/view/273/158

Pithouse, K. (2003). What is this? What is this? What is this? A teacher's personal narrative inquiry into a memorable curriculum experience (Unpublished master's thesis). University of Natal, South Africa. Retrieved from http://researchspace.ukzn.ac.za/xmlui/handle/10413/3686

Pithouse, K. (2004). "This gave us a chance to feel like we are authors": A chapter in my story of learning to teach writing. English Quarterly, 36(10), 15-17. 
Pithouse, K., Mitchell, C., \& Weber, S. (2009). Self-study in teaching and teacher development: A call to action. Educational Action Research, 17(1), 43-62.

Pithouse-Morgan, K., Deer-Standup, S. O., \& Ndaleni, T. (2019). Stories blending, flowing out: Connecting teacher professional learning, re-membering, and storytelling. In K. Pithouse-Morgan, D. Pillay, \& C. Mitchell (Eds.), Memory mosaics: Researching teacher professional learning through artful memory-work (pp. 155-173). Cham, Switzerland: Springer.

Samaras, A. P. (2011). Self-study teacher research: Improving your practice through collaborative inquiry. Thousand Oaks, USA: SAGE.

Samaras, A. P., Hicks, M. A., \& Berger, J. G. (2004). Self-study through personal history. In J. J. Loughran, M. L. Hamilton, V. K. LaBoskey, \& T. Russell (Eds.), International handbook of self-study of teaching and teacher education practices (Vol. 2, pp. 905-942). Dordrecht, Netherlands: Kluwer.

Samaras, A., \& Roberts, L. (2011). Flying solo: Teachers take charge of their learning through self-study research. Learning Forward, 32(5), 42-45.

Social Media in Learning and Education (SMILE). (2013). Challenges and opportunities for schools and teachers in a digital world: Lessons learned from the 2012 SMILE action research project.

Retrieved from http://www.eun.org/c/document library/get file?uuid=232671ea-32ca-42728b24-20328aafe8bb\&groupld=43887

Township. (n.d.). In Oxforddictionaries.com. Retrieved from https://en.oxforddictionaries.com/definition/township 